\title{
Improving Vocational Teacher Professionalism through Lesson Study
}

\author{
Abdul Muis Mappalotteng \\ Department Of Electrical Engineering Education, State University of Makassar
}

\begin{abstract}
The increasing number of Vocational High Schools (VHS), as the government policy to VHS increasing ratio and high school teachers led to claim the higher vocational education. However, on the side must also be quality, such as the professionalism of teachers. A vocational teacher who is able to adapt to professional students, are able to transfer knowledge and skills.

Vocational teachers are productive Program teachers. So that vocational teacher professionalism can be enhanced, of course there are many ways that can be applied, among other lesson study. Lesson Study is a model of professional development of teachers through the collaborative learning and development based on principles colleagues and mutual learning to build a learning community; Implemented with lesson study in SMK, and vocational teachers can share knowledge and skills of teachers and other, and even can be used as media for continuing education.

Lesson study is carried out consists of 3 main phases, namely: Plan of the excavation on academic topics, and learning tools that are used; Implementing a learning plan based on lessons learned and tools provided, and invite colleagues to observe same of the level; Implementing reflection through the various opinions and discussion with the observer.
\end{abstract}

Keywords: Professionalism, Vocational Teacher, Lesson Study

\section{Introduction}

Education Ministry continue to increase the ratio of SMK and SMA, which currently is 50: 50 (number of school SMK = 7719) with the target until the year 2014 to be 67: 33 (number of VHS schools $=9793$ ), [even the Ministry of National Education policy 70: 30 ratio in end of the year 2015 according to Gumilang [1] in his Thesis in the ITB]. Increasing the amount of how to create a new VHS and conversion High School to VHS.

Increasing the number of VHS is of course must be accompanied by improving the quality and quantity of teachers, especially so that the quality of vocational teachers from VHS that can compete worldwide and the international industry. Therefore, during the learning process that is less attention from either of the parents or the government must searching solutions, both by parents, teachers and the government itself.

In general, the learning process going on in class that no one knows except the teachers themselves. Most of the supervisors from the district education office have not functioned as a supervisor of learning in the classroom. Supervisors rarely entered the classroom and workshop learning to make observations and to be sources of learning for teachers in schools. So also the school principal. Principals generally more teachers to the administrative documents, such as lesson plan of the incoming class to observation and supervision of learning by a teacher. As a result, teachers do not challenge preparation to teach well, to think that teaching methods vary, prepare materials for experimental in the laboratory.

Generally, learning is done in the form of one-way. Teachers more lectures before the students' activities while the students listen more. There are teachers who think only of its duty to transfer knowledge of the target reach with the topics of a document written in the curriculum. In general, teachers do not provide inspiration to the students to create and does not train students for independent living.

To overcome these things teachers need to do a lesson study, so that teachers can do a review of its performance can be further used as inputs to improve their performance. With implementing lesson study, teachers will develop insight and always motivated to innovate, which then became a professional teacher.

\section{Competency Vocational Teacher Professionalism}

The Birth of Law Number 14 Year 2005 on Teachers and lecturers are the government efforts in improving the quality of education in the country. One of the important points of law is a teacher as a profession. Teachers must have the professional competence and academic competence as a professional integrity. Pedagogical competence, professional, personality, social, and formulated in the Law No. 14 Year 2005 should be seen as an integrity that is not separated from control of the competency of teaching materials in the curriculum [2]

Meanwhile, a teacher of vocational teachers is a program (groups of subjects) productive. Vocational technology that includes, among others, is the program expertise in the field of engineering construction, 
engineering and electrical engineering. If compared with the group of teachers of subjects normative and adaptive (Indonesia language, PPKn, Mathematics, etc.) vocational teachers' productive groups in general have academic requirements that are not different, that is education is S1 or D4, have pedagogical competence, personality, professional and social. However, teachers have a productive program characteristics and requirements (competency) of a specific professional, namely, among others: 1 . Having adequate practical skills in all fields of study (subjects) productive; 2. Capable of holding (Training) with the relevant competencies needed by the world of work; 3 . Ability to design learning (Training) in schools and in the business or industry.

Vocational High School (VHS) Teachers in Indonesia based on Statistical schooling VHS in 2005 as many as 155,761 people with the details of teachers who are teachers as much as 52,732 civil servants and non civil servants, the 103,029 people who were scattered in the 4480 VHS (796 are public and private sector as 3684). Based on the level of education that can views in the table below shows that 4.18 percent of the educated with the D1 or above but below the D2 and D3 especially S1, S2 or S3. Given the existing levels of education, then that can be delivered $21.38 \%$ (33,297 people) are not feasible because the levels of education are not in accordance with the competencies required [3].

How do I increase the competence-competence above? Lesson Study can provide a solution, because it is a lesson study model of professional learning of teachers through a collaborative and based on sustainable principles colleagues and mutual learning to build a learning community. Teachers in collaborative, first analyze the problem of learning, both from the material aspects of teaching and learning methods [4]. Next is also the collaborative search for solutions and educators to design learning that is based on the students. The next step is to apply the learning at class by a teacher, while another observer as a student activity resumed with a discussion of learning for post- cause of reflection if the principles of lesson study is done in a systemic and sustainable will possible impact on the quality of vocational education in Indonesia.

\section{Lesson Study For The Improvement Of Vocational Teacher Professional}

Lesson Study is a model of professional development of teachers through the collaborative learning and development based on principles collegiality and mutual learning to build a learning community. Thus, Lesson Study is not a method or strategy of Lesson Study activities, but can apply various methods / learning strategies appropriate to the situation, conditions, and problems faced by teachers. Lesson study can be done by a number of specialist teachers and learning that include a three (3) the activities, including planning (planning), implementation (action) learning and observation and reflection (reflection) of the planning and implementation of these, in order to improve the quality of learning.

Lesson Study is essentially a form of teacher professional development activities that characterized the teacher to open the management lessons for other peer teachers as Observer, to enable teachers to share learning experiences with of the same level. Lesson study is a process of training teachers who have cycle, beginning with a teacher: 1) plan of academic subjects through the exploration of the teaching materials and learning tools; 2) make a plan based on learning and learning tools that are made, of the same level to invite observation; 3 ) to the reflection of the earlier studies through the exchange of views, reviews, and discussions with the Observer. Therefore, the implementation of lesson study program should be monitored and evaluated so that it will be known how the effectiveness, efficiency acquisition and the parties involved in it [4].

Lesson study as one of the program activities to improve competence of teachers and quality learning can be developed in schools as a study for the analysis of a learning practice that was conducted in the form of learning-based research to find a specific learning innovation.

Lesson study implemented and selected for several reasons. First, the lesson study is an effective way that can improve the quality of the teacher and student activities. This is because (1) development of lesson study is done and the results are based on "sharing" knowledge to the professional practice and teaching of the teachers implemented, (2) emphasis on the implementation of a fundamental lesson study is that students have quality learning, (3) competencies which students are expected to belong to, as the focus point and focus in learning in the classroom, (4) based on real experiences in the classroom, lesson study is able to become the basis for the development of learning, and (5) lesson study will put the role of teachers as researchers learning [7].

Second, the lesson study designed with a good teacher will make a professional and innovative. Implementing lesson study with teachers can [6]:

- determine the competencies that need to be owned by students, plan and implement learning (lesson) is effective;

- review and improve the lessons that are useful for students;

- deepen the knowledge of the subjects who presented the teachers;

- determine the standards of competence that the students will be achieved;

- a collaborative lesson plan;

- carefully review the study and student behavior; 
- develop a knowledge of reliable and

- to the reflection of the implementation of teaching based on the view that students and colleagues.

Wang-Iverson and Yoshida said that the lesson study has several benefits as follows [4].

- $\quad$ Reduce teachers remote (from the community)

- Helping teachers to scrutinize observation and that instruction

- Deepen teachers' understanding of lesson material, the scope and sequence of material in the curriculum.

- Help teachers focus on all the activities help students learn.

- Create knowledge about the occurrence of the students think and learn

- Increase collaboration among the teachers.

\section{The Implementation Of Lesson Study}

In the implementation of lesson study conducted by JICA-IMSTEP in Indonesia, [2] introduce lesson study oriented practices. Lesson study is carried out consists of 3 main phases, namely: (1) Plan of the excavation on academic topics, and learning tools that are used, the next stage, called the Plan, (2) Implementing a learning plan based on learning and tool - equipment provided, and invite colleagues to observe of the same level. This activity is called phase I, (3) Conduct reflecting a variety of opinions / feedback and discussion with the observer [5].

\section{A. Planning}

At this stage, made the identification problem is in the class that will be used for lesson planning and study alternative solutions. Identify the problem in the framework of the planning problem solving is related to the main criticism (subject material) that are relevant to the class schedule and tuition, student characteristics and atmosphere of the class, method / approach to learning, media, tools, and evaluation process and results of learning.

From the results of the identification is discussed (in lesson study groups) on the selection of learning materials, the selection method and the media in accordance with the characteristics of students, and the type of evaluation that will be used. At the time of discussion, will appear discordant opinions and suggestions from teachers and experts in the group to set the options that will be applied. At this stage, the expert can bring important things / that needs to be known and applied by teachers, such as constructive learning approach, learning approach, students learn the independency, contextual learning, the development of life skills, Realistic Mathematics Education, updating teaching materials, or other that can be used as a consideration in selecting it.

It is also important is the preparation for the discussion of observations, especially the determination of aspects that need to be in a process and indicator-indicator, particularly in terms of the behavior of students. Aspects of the process and indicators that are developed based on a learning device that is made and the basic competencies set for the students held after the process of learning.

From the results of the identification and discussion of planning issues to solve, then prepared and packed in a learning device which consists of:

1. Learning Plan (RPP)

2. Implementation instructions Learning (Teaching Guide)

3. Student Work Sheet (LKS)

4. Media or tools of learning

5. Assessment instruments and results of the process of learning.

6. Sheet observation of learning.

The preparation of this device can be made by a teacher or some teachers on the basis of agreement on aspects of learning which is planned as a result of the discussion. A result of the preparation device is necessary consultation with the lecturer or teacher who is seen in the specialist group to be refined.

Planning that can also be arranged vice versa, that is one or more of the teachers assigned in groups to identify problems and plan solutions in the form of devices for learning a subject in a discussion of subjects that have been determined in the group. Furthermore, the identification of learning problems and the device is to be discussed.

\section{B. Implementation and Observation}

At this stage, a teacher who has been appointed (approved) by the group, making the implementation of the implementation of the plan (RPP), which have been developed, and in the classroom. Specialist teachers and others with the observation using the observation that has been prepared and other devices required. The Observer this record things positive and negative in the learning process, particularly in terms of the behavior of students. In addition (if possible), made video recordings (audio visual) those close-up special events (on the teachers or students) during the learning process. Recording the results are useful later as evidence authentic 
events that need to be discussed in the reflection on the seminar or lesson study results, in addition, can be used as material for dissemination to a wider audience.

\section{Reflection}

Finish the practice of learning, reflection is done immediately. At this stage of reflection, the teacher appears, and the Observer and experts held discussions on a new course of learning to do. Discussion is led by the Principal, Coordinator of the group, or teachers who are appointed by the group. First teachers who implemented the plan of learning are given the opportunity to reveal the effect of carrying during learning, both of him and of the students faced.

Furthermore Observer (teachers and other experts) the results of data analysis from observation, especially regarding the activities held during the students' learning that comes with playing the video recording of the results. Next, the teacher who implemented it will provide feedback comments on the back of the Observer. It is also important in this stage of reflection is to consider re-learning plan that had been developed as a basis for the improvement of the next plan. Whether the plan was appropriate learning can improve performance and active student learning. If you have no rapport, things are not appropriate, educational method, the materials in LKS, the media or tools, or other. Considerations are used to improve the plan further learning.

\section{Conclusion}

Based on the description-the description above can be: (1) vocational teachers are productive program teachers, (2) Study the lesson of a model of professional development of teachers through the collaborative learning and development based on principles of mutual learning and colleagues to build a learning community; (3) Lesson study conducted consists of 3 main phases, namely: Plan of the excavation on academic topics, and learning tools that are used; Implementing a learning plan based on lessons learned and tools provided, and invite colleagues to observe of the same level; Implementing reflection through the various opinions and discussion with the observer.

\section{Reference}

[1]. Gumilang, Gumilar Wahyu. (2008). Kajian Penerapan Kebijakan Pengembangan Sekolah Menengah untuk Mendukung Kegiatan Ekonomi di Provinsi DKI Jakarta. Bandung: ITB

[2]. Indonesia (2005). Undang-Undang Republik Indonesia Nomor 14 Tahun 2005 Tentang Guru dan Dosen

[3]. Saito, E., Imansyah, H. dan Ibrohim. 2005. Penerapan Studi Pembelajaran di Indonesia: Studi Kasus dari IMSTEP . Jurnal Pendidikan "Mimbar Pendidikan", No.3. Th. XXIV: 24-32.

[4]. Takashi A. (2006). Implementing lesson study in North American schools and school (makalah yang dipresentasikan pada seminar "APEC International)

[5]. Jica FPMIPA UPI (2006) Lesson Study Suatu strategi untuk meningkatkan keprofesionalan pendidik. UPI Press

[6]. Asep Z. Argawinata. 2009. Bagaimana melakukan lesson study? (On line): downloaded 12 Agustus 2009, dari: http://www.lpmpjabar.go.id/ index.php/artikel/162-bagaimana-melaksanakan-lesson-study

[7]. Lewis, Catherine C. (2002). Lesson study: A Handbook of Teacher-Led Instructional Change. Philadelphia, PA: Research for Better Schools, Inc. 